\title{
Neurotoxicity of calcineurin inhibitors: Tacrolimus
}

\author{
Marco J. Flores-Aldama and Fernando D. Flores-Silva* \\ Departamento de Neurología y Psiquiatría, Instituto Nacional de Ciencias Médicas y Nutrición Salvador Zubirán, Mexico City, Mexico
}

\begin{abstract}
At the beginning of this century, calcineurin inhibitors, especially tacrolimus, were the treatment of choice for immunosuppression in solid organs. It is known that in recent years, the incidence of renal and hepatic transplants has increased up to $15 \%$, and therefore, a compelling reason why immunosuppression treatment is more relevant to reduce rejection, morbidity, and mortality rates. Although the systemic complications of the use of calcineurin inhibitors are known, there is still little information on its neurotoxic effects; however, a prevalence in up to $28 \%$ is estimated with a broad spectrum of clinical and radiological manifestations. The relevance of this work lies in describing the phenomenon of neurotoxicity, its clinicaland radiological manifestations, risk factors, and management.
\end{abstract}

Key words: Neurotoxicity. Tacrolimus. Tremor. Transplant.

\section{Neurotoxicidad de los inhibidores de la calcineurina: tacrolimus}

\section{Resumen}

A principios de este siglo, los inhibidores de la calcineurina, especialmente el tacrolimus, eran el tratamiento de elección para la inmunosupresión en órganos sólidos. Se sabe que en los últimos años, la incidencia de trasplantes renales y hepáticoş ha aumentado hasta un 15\% y, por lo tanto, una razón poderosa por la cual el tratamiento de inmunosupresión es más relevante para reducir las tazas de rechazo, morbilidad y mortalidad. Aunque se conocen las complicaciones sistémicas del ușo de inhibidores de calcineurina, todavía hay poca información sobre sus efectos neurotóxicos. Sin embargo, se estima una prevalencia de hasta el $28 \%$ con un amplio espectro de manifestaciones clínicas y radiológicas. La relevancia de este trabajo radica en describir el fenómeno de la neurotoxicidad, sus manifestaciones clínicas y radiológicas, factores de riesgo y geștión.

Palabras clave: Neurotoxicidad. Tacrolimus Temblor. Trasplante.

\section{Introduction}

Tacrolimus (FK-509 or fujimycin) is a macrolide inhibitor of calcineurin which limits the signaling of $\mathrm{T}$ lymphocytes and transcription of IL-2; therefore, it is a pillar in the treatment of immunosuppression after the transplant of solid organs worldwide, confirmingthe protocol Elite-Symphony in $2007^{1}$.

The toxic effects related to calcineurin inhibitors are mostly metabolic (hypercholesterolemia and hyperglycemia), nephrotoxic, hematological, and neoplastic and infectious alterations.

\section{Correspondence:}

*Fernando Daniel Flores Silva

Departamento de Neurología y Psiquiatría, Instituto

Nacional de Ciencias Médicas y Nutrición Salvador

Date of reception: 13-04-2019

Date of acceptance: 12-06-2019

DOI: 10.24875/RMN.19000073
Available online: 04-12-2019 Rev Mex Neuroci. 2019;20(6):28ㄴ-287 www.revmexneurociencia.com

E-mail: ferfs98@gmail.com

1665-5044/C 2019 Academia Mexicana de Neurología A.C. Published by Permanyer. This is an open access article under the CC BY-NC-ND license (bttp:// creativecommons.org/licenses/by-nc-nd/4.0/). 
Neurological complications have been the least studied despite presenting a relevant prevalence between 10 and $28 \%$, containing a broad spectrum of manifestations ranging from mood changes to $\mathrm{coma}^{2}$.

In the review of the literature, there is limited information and not a lot of studies conducted to assess the neurological complications in this group. Muller et al. ${ }^{3}$ described post-operative neurological complications due to the use of tacrolimus in post-transplant liver patients.

It has been reported that the risk factors for developing neurological complications are hepatic failure, systemic hypertension, hypocholesterolemia, and high levels and concomitant use of methylprednisolone. However, it should be noted that many of the risk factors and complications present difficulties in establishing causality since many of these patients have multiple comorbidities and use other immunosuppressants ${ }^{2}$.

Although the association of neurological complications and tacrolimus is known, comparative studies between transplants of different organs in the long term are not yet available.

Tacrolimus has a great variability in its interindividual pharmacokinetics, so traditional dosing schemes are often obsolete and must be individualized from patient to patient. Therefore, constant monitoring of serum levels is important. It is known that reaching adequate serum levels is essential in the post-transplant period to avoid rejection, but it is still unknown at what speed and neurotoxic levels ${ }^{4}$.

The metabolism of tacrolimus is mainly hepatic in cytochrome P450 3A5, so alterations in this cytochrome can cause an erratic bioavailability, but it has been seen that the levels of hematocrit, weight, and use of steroids can also interfere ${ }^{5}$.

It has been observed that during the $1^{\text {st }}$ year post-op, serum levels can change despite maintaining the same doses, therefore, up to $60 \%$ of patients will have non-therapeutic doses. Most physicians will establish the dose based on their clinical experience and will not use different tools designed for this purpose such as the use of specialized programs or measurement of CYP3A4 ${ }^{6}$.

\section{Neurotoxicity}

As previously mentioned, neurological complications can be found in up to $28 \%$ of the transplanted patients, but characteristics will differ depending on the transplanted organ and serum levels.

There is also a lack of evidence of the use of calcineurin inhibitors in the different transplanted organs,
Table 1. More frequent neurological manifestations divided by severity

\begin{tabular}{|l|l|l|}
\hline Mild & Moderate & Severe \\
\hline Tremor & $\begin{array}{l}\text { Visual } \\
\text { alterations }\end{array}$ & $\begin{array}{l}\text { Coma/Altered } \\
\text { consciousness }\end{array}$ \\
\hline Headache & $\begin{array}{l}\text { Cortical } \\
\text { blindness }\end{array}$ & Confusion \\
\hline $\begin{array}{l}\text { Mood } \\
\text { alterations }\end{array}$ & PRES & Psychosis \\
\hline $\begin{array}{l}\text { Neuralgia } \\
\text { Apraxia of } \\
\text { speech }\end{array}$ & Seizures \\
\hline $\begin{array}{l}\text { Peripheral } \\
\text { neuropathy }\end{array}$ & & Leukoencephalopathy \\
\hline
\end{tabular}

and therefore, a failure in the prevention of complications, in addition to the lack of follow-up in long-term complications. In the case of kidney transplantation up to $60 \%$ of patients have tremor during their follow-up appointments?

It is suggested that the mechanism of the neurotoxic effect is based on selected toxicity to glial cells and induction of oligodendrocyte apoptosis, but the clinical manifestation will depend on the time and severity of the exposure ${ }^{8}$.

Complications can be divided according to their severity: mild, moderate, and severe. Not only the most frequent manifestation that we can find is tremor followed by headache, but also manifestations of both the central and peripheral nervous systems are frequently found (Table 1).

Less severe symptoms such as tremor or paresthesia can last months to years and revert spontaneoúsly. Some of the more severe complications, such as visual blindness, are associated with an abrupt increase in tacrolimus levels. Multiple reports of paraplegia, symmetric polyneuropathy, dysarthria, and encephalopatthy have been also reported in the literature.

Unlike kidney transplantation, a greater number of complications have been observed in liver transplantation, due to different mechanisms such as alteration in metabolism and circulating metabolites. The mostffrequent manifestations in these patients are alterations in the state of consciousness and seizures, and usually more severe manifestations ${ }^{9}$.

\section{Sympathetic system}

One of the most frequent complications of the use of tacrolimus is systemic arterial hypertension, but it is a consequence of a sympathetic dysfunction, possibly 


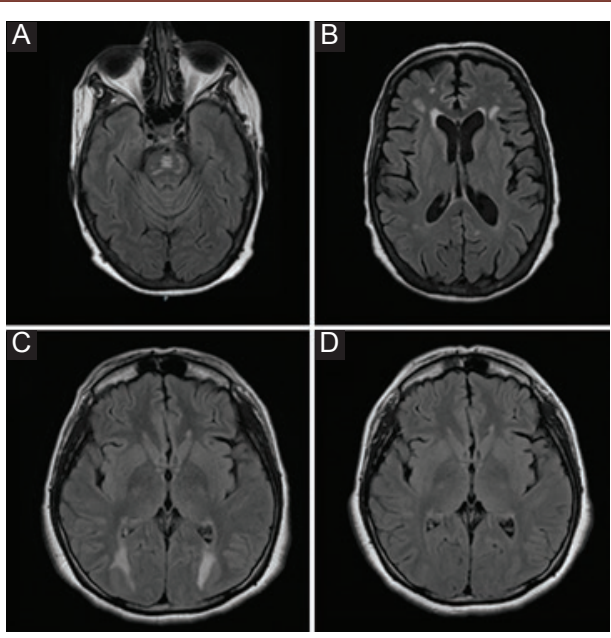

Figure 1. Most frequent radiological findings. A: T2 FLAIR sequence: hyperintense lesion in the pontine region corresponding to pontine myelinolysis. B: T2 FLAIR Sequence: multiple intra-axial hyperintense images located diffusely in white matter in relation to leukopathy. C: FLAIR T2 sequence: hyperintense intraxial images symmetrically in the occipital region. D: Control image 3 months later with reversibility of the lesions compatible with posterior reversible encephalopathy syndrome (PRES).

due to a modulation of NMDA and GABA receptors and modulating pre- and post-synaptic glutaminergic receptors ${ }^{10}$.

\section{Clinical impact}

In patients, a decrease in quality of life and an increase in morbidity and mortality have been observed, especially in liver transplant patients. In the first instance, severe complications can increase risk of death, but moderate complications can result in transplant rejection. Furthermore, systemic hypertension being a frequent complication results in cardiovascular and cerebrovascular risks. It is important to note that some of the complications will not be reversible ${ }^{11}$.

\section{Image studies}

The diagnostic standard is MRI, its indication focuses on moderate-to-severe complications such as in the case of seizures, altered state of consciousness, cortical blindness, and speech alterations. There are no prospective studies of the alterations by imaging, but a predilection for involvement of the white matter in the occipital region has been observed. In post-liver transplant patients, pontine and extra-pontine myelinolysis have also been identified (Fig. 1) ${ }^{12}$.

\section{Management and treatment}

The broad spectrum of manifestations should be treated first in a symptomatic way, and studies on serum levels should be carried out at the same time, also electrolytes should be measured, monitoring blood pressure, and evaluating imaging or neurophysiological studies are highly recommended.

If the serum levels are high and mild-to-moderate manifestations, the dose can be gradually decreásed and the response assessed, while in severe symptoms the most appropriate is the suspension and adjustment of immunosuppression.

In the symptomatic treatment, the use of anticonvulsants, phenytoin, phenobarbital, and carbamazepine should be avoided since having the hepatic metabolism, serum levels might become erratic. Although empiriçally, the use of valproic acid and levetiracetam is recommended. Finally, it is recommended to control blood presşure levels and electrolyte alterations, mainly magnesium, which is a factor for the development of seizures ${ }^{13}$.

\section{Conclusions}

Tacrolimus is essential in the treatment of immünosuppression in the transplantation of solid organs but its neurotoxic effects have a significant impact onthe morbidity and mortality of patients. Patients with fiver transplantation should be more vigilant because offthe number of complications and severity.

In Mexico, as in the rest of the world, the rate of transplants is increasing, so these complicationso will become more frequent, and protocols for surveillance, prevention, and treatment must be developed.

\section{Ethical disclosures}

Protection of human and animal subjects. The authors declare that the procedures followed were in accordance with the regulations of the relevant clinical research ethics committee and with those of the Code of Ethics of the World Medical Association (Declaration of Helsinki).

Confidentiality of data. The authors declare that they have followed the protocols of their work center on the publication of patient data.

Right to privacy and informed consent. The authors declare that no patient data appear in this article.

\section{References}

1. Ekberg H, Tedesco-Silva H, Demirbas A, Vítko S, Nashan B, Gürkan A et al. Reduced exposure to calcineurin inhibitors in renal transplantation. N Engl J Med. 2007;357:2562-75. 
2. Bechstein WO. Neurotoxicity of calcineurin inhibitors: impact and clinical management. Transpl Int. 2000;13:313-26.

3. Mueller AR, Platz KP, Bechstein WO, Schattenfroh N, Stoltenburg-Didinger G, Blumhardt G, et al. Neurotoxicity after orthotopic liver transplantation. A comparison between cyclosporine and FK506. Transplantation. 1994;58:155-70.

4. Kershner RP, Fitzsimmons WE. Relationship of FK506 whole blood concentrations and efficacy and toxicity after liver and kidney transplantation. Transplantation. 1996:62:920-6.

5. Brooks E, Tett SE, Isbel NM, Staatz CE. Population pharmacokinetic modelling and Bayesian estimation of tacrolimus exposure: is this clinically useful for dosage prediction yet? Clin Pharmacokinet. 2016:55:1295-335.

6. Woillard JB, Saint-Marcoux F, Debord J, Åsberg A. Pharmacokinetic models to assist the prescriber in choosing the best tacrolimus dose. Pharmacol Res. 2018;130:316-21.

7. Erro R, Bacchin R, Magrinelli F, Tomei P, Geroin C, Squintani G, et al. Tremor induced by calcineurin inhibitor immunosuppression: a single-centre observational study in kidney transplanted patients. J Neurol. 2018;265:1676-83.
8. McDonald JW, Goldberg MP, Gwag BJ, Chi SI, Choi DW. Cyclosporine induces neuronal apoptosis and selective oligodendrocyte death in cortical cultures. Ann Neurol. 1996;40:750-8.

9. Guarino M, Stracciari A, Pazzaglia P, Sterzi R, Santilli I, Donato Flet al. Neurological complications of liver transplantation. J Neurol. 1996; 243:137-42.

10. Sander M, Lyson T, Thomas GD, Victor RG. Sympathetic Feural mechanisms of cyclosporine-induced hypertension. Am J Hypertens. 1996;9:121S-38

11. Wijdicks EF, Wiesner RH, Dahlke LJ, Krom RA. FK506-induced neurotoxicity in liver transplantation. Ann Neurol. 1994;35:498-501.

12. Fryer JP, Fortier MV, Metrakos P, Verran DJ, Asfar SK, Pelz DM, et al. Central pontine myelinolysis and cyclosporine neurotoxicity following liver transplantation. Transplantation. 1996;61:658-61.

13. Bronster DJ, Emre S, Mor E, Sheiner P, Miller CM, Schwartz ME, et al. Neurologic complications of orthotopic liver transplantation. Mt Sinai JMed. 1994;61:63-9. 